UDC 33.025.12-049.5:338.43

DOI: $10.15673 /$ fie.v11i3.1458

\author{
Gryshova I. \\ Doctor of Economic Sciences, Professor \\ Jiangsu Normal University \\ 101 Shanghai Rd, Tongshan Qu, Xuzhou Shi, \\ Jiangsu Sheng, China, 221100 \\ E-mail:6020180146@jsnu.edu.cn \\ ORCID ID: 0000-0001-6276-7619
}

\author{
Nikoliuk 0. \\ Doctor of Economics, Associate Professor \\ Department of Management and Logistics \\ Odessa National Academy of Food Technologies \\ Kanatna str., 112, Odesa, Ukraine, 65039 \\ E-mail: alenavn11@gmail.com \\ ORCID ID: 0000-0002-1665-0361
}

\author{
Marchuk L. \\ $\mathrm{PhD}$ in Economics, Lecturer \\ Department of Economics and Management \\ Odessa State Academy of Technical Regulation and Quality \\ st. Kuznechnoe, $15 \mathrm{~m}$. Odessa, Ukraine, 65020 \\ E-mail: IIm.15456@gmail.com
}

\title{
INSTITUTIONAL ASPECTS OF THE REGULATION OF ECONOMIC SECURITY OF THE AGRICULTURAL PRODUCTION
}

The article considers the regulation of economic security of the agricultural production as a complex integrated element of the general system of innovative development of agricultural production at all levels of its regulation, and provides for the implementation of appropriate measures (organizational-technological, preventive, propaganda, controlling, protective) that are used to counteract the negative impact on the economic security of agricultural production. In this connection, the strategic objectives of regulating the economic security of the agricultural production have been identified, which will contribute to the development of specific measures to eliminate threats in this area. The list of institutional factors (economic, environmental, social and technical and technological) and the components of regulation of economic security of agricultural production has been presented, a comprehensive set of which provides the most accurate reflection of the essence and direction of the dangers and threats that the national economy, in particular, agricultural production, may suffer in the process of functioning and innovative development.

Keywords: economic security, agricultural production, regulatory policy, institutional aspects, strategy, innovation development.

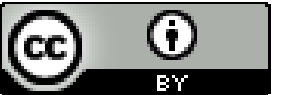

This work is licensed under a Creative Commons Attribution 4.0 International License http://creativecommons.org/licenses/by/4.0/
Statement of the problem and its connection with important scientific and practical tasks. In the conditions of complete economic independence, the subjects of the agricultural production themselves determine their economic policy, organize the production process and sale of products and bear full responsibility for the results of their production and economic activity. All this, largely requires from managers to form an effective system for regulating economic security, which operates under the influence of a combination of factors. The main purpose of the regulation of the economic security of the agricultural production is to ensure its stability and the most efficient operation in terms of the innovative development. Regulation of the economic security of the agricultural production includes the following areas: protection of material and financial values; protection of intellectual property and human resources; protection of the information and consulting environment; protection and prospects updating the material and technical base; environmental protection (compliance with the principle of environmental production).

The analysis of the latest publications on the problem. The scientific works of I. Grishov [3], A. Dyachenko [9], S. Kushnir [6], M. Malik [7], A. Nikolyuk [8], V. Rusan [9], P. Sabluka [10] and others are devoted to. The study of the problems of regulation to ensure the economic security of the agricultural production. The basis for deepening the theoretical and practical aspects of agricultural production were the works of such domestic scientists as V. Andriychuk [1], T. Gnatievoi [2], V. Kozlovsky [4], A. Konarivskoi [5], A. Shpikulyak [7], I. Gryshova [11], N. Kuprina [13], I. Myshchak [14], T. Stupnytska [15] and others. Noting the importance of scientific and practical developments of these authors, it should be noted that there is a need to deepen the theoretical approaches to the regulation of economic safety of agricultural production. The issue of ensuring the economic security of the agricultural production is explained in a fragmented manner in the theory of state regulation. The components of the strategy to ensure the economic security of agricultural production based on innovative development require further scientific study. The urgency of solving the problems of ensuring the economic security of agricultural production as an important component of ensuring food security of the national economy of Ukraine, the search for new approaches to the formation of an appropriate strategy, mechanisms for regulating the economic security of agricultural production and their organizational and informational support determined the formulation of the research objectives. 
Forming of the aims of the research. The purpose of the article is to substantiate the theoreticmethodological foundations and develop the practical recommendations for improving the institutional aspects of regulating the economic security of the agricultural production in Ukraine; it identified a number of tasks: to reveal the components of the system of regulation of the economic security of the agricultural production; to carry out a comprehensive analytical assessment of the effectiveness of the state regulation of ensuring the economic security of the agricultural production in Ukraine; to formulate proposals for the development of a strategy for ensuring the economic security of the agricultural production in Ukraine and the stages of its implementation.

Giving an account of the main results and their substantiation. The result of the regulation of the economic security of the agricultural production is the stability of its operations, the effectiveness of financial and economic activity and the safety of each employee.

Depending on subjective conditionality, all ne- gative phenomena affecting the economic security of agricultural production can be divided into objective and subjective. Objective problems are those that arise not through the fault of the subjects of agricultural production or its individual participants. Subjective problems arise from the ineffective functioning of agricultural entities. In order to neutralize the impact of negative phenomena on the activities of the agricultural production, in the framework of this study, a systematization of internal and external factors, affecting the regulation of the economic security of the agricultural production was carried out. This approach is intended to combine internal goals in the system of regulating the economic security of the agricultural production aimed at neutralizing possible risks, increasing the efficiency of the agricultural production, developing rural territories and meeting the social needs of peasants with external ones that ensure food security, export potential, innovative development of the agricultural production and preserving of the surrounding natural environment in the country (Fig. 1.).

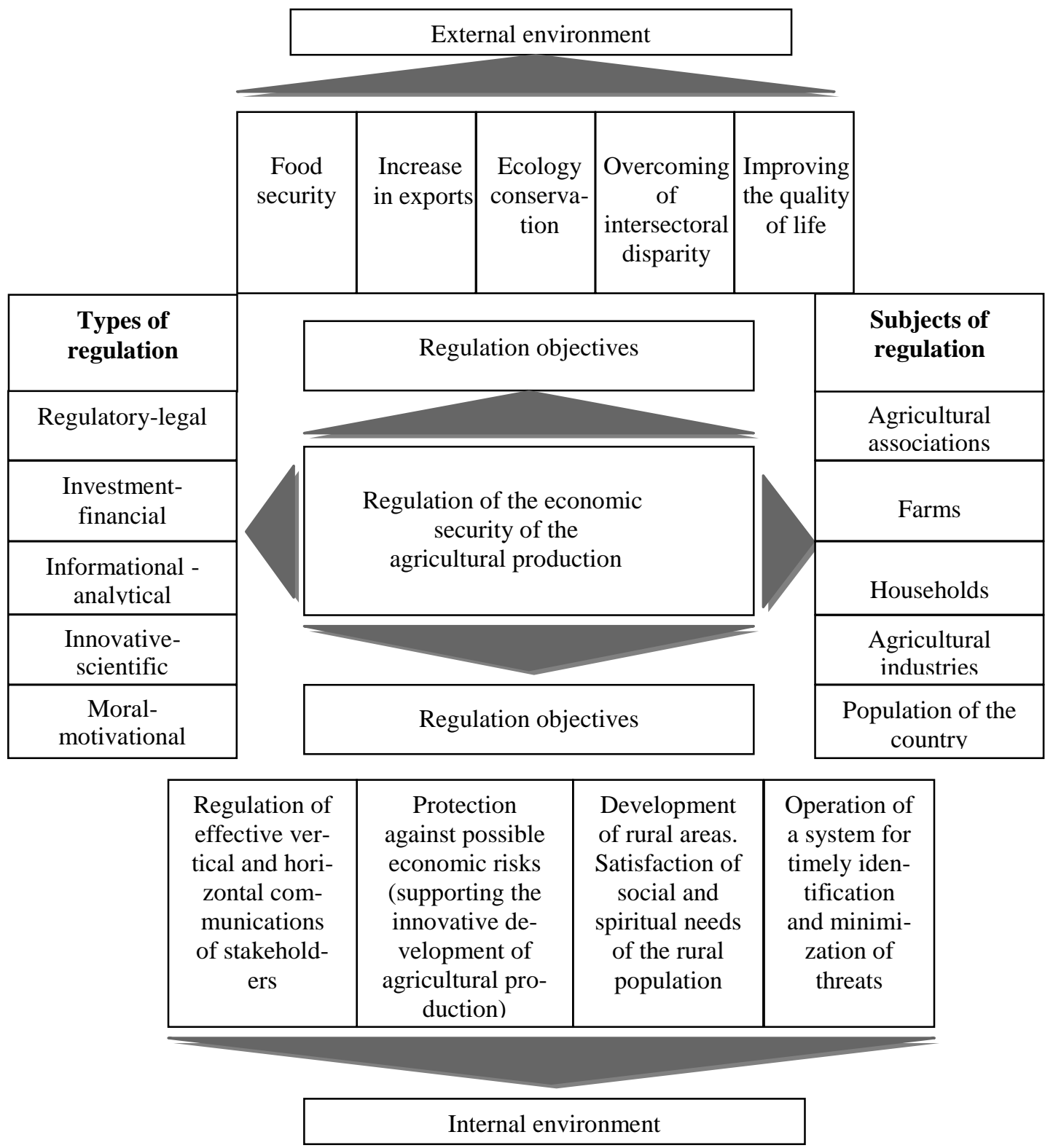

Fig. 1. The environment of the regulatory policy of the economic security of the agricultural production* * compiled by the authors 
This approach to the functioning of the environment of regulation of the economic security of the agricultural production makes it possible to comprehensively apply all types of regulation regarding agricultural production (regulatory-legal, investment and financial, information-analytical; innovation-scientific; moralmotivational), especially taking into account that historically the key carrier and the factor of effective activity of agrarian production is the person with the whole complex of his own moral, ethical, mental and religious preferences.

However, even the unquestioned understanding that all socio-economic macroeconomic processes occur at the level of individuals does not in any way deny the existence of systemic synergistic effects that arise in complex systems, and therefore cannot be explained by the properties of their component parts.

Regulation of the economic security of the agricultural production is primarily determined by the characteristics of socio-economic relations in the agricultural sector. Thus, sharing the views of scientists, V. Andriychuk, T. Gnatievoi, S. Kushnir, M. Malik, P. Sabluka [1, $2,6,7,10]$, we systematized the functioning factors of agricultural production, which affect its regulation of economic security (table 1).

Factors of agricultural production functioning that affect the regulation policy of economic security *

\begin{tabular}{|c|c|c|}
\hline Factor & Characteristics of a factor & $\begin{array}{l}\text { Methods of optimizing the influence } \\
\text { of factors }\end{array}$ \\
\hline \multicolumn{3}{|c|}{ Technological conditions of production } \\
\hline $\begin{array}{l}\text { Natural } \\
\text { phenomena }\end{array}$ & $\begin{array}{l}\text { Crop failure, floods, droughts and other natural } \\
\text { disasters } \\
\text { Dependence on weather and climatic conditions }\end{array}$ & $\begin{array}{l}\text { Creation of state, regional, sectoral and inter- } \\
\text { nal-economic insurance and reserve funds }\end{array}$ \\
\hline Seasonality & $\begin{array}{l}\text { The discrepancy between the production period } \\
\text { and the sales period of production is related to the } \\
\text { duration of the production cycle }\end{array}$ & $\begin{array}{l}\text { Interaction with banks, on the formation of } \\
\text { the system of preferential lending, state fi- } \\
\text { nancial support in the form of compensation } \\
\text { of interest on loans }\end{array}$ \\
\hline \multicolumn{3}{|c|}{ The nature of work and production technology } \\
\hline Land & $\begin{array}{l}\text { Is not amortized and therefore is not involved in } \\
\text { the formation of production costs }\end{array}$ & $\begin{array}{l}\text { State regulation of differentiated income } \\
\text { (rent) of farmers, depending on the level of } \\
\text { fertility and location }\end{array}$ \\
\hline $\begin{array}{l}\text { Breeding and } \\
\text { working } \\
\text { livestock }\end{array}$ & $\begin{array}{l}\text { Depreciation is not calculated on breeding lives- } \\
\text { tock, its value is not transferred to the cost of pro- } \\
\text { duction, but it is calculated on working livestock }\end{array}$ & $\begin{array}{l}\text { Organization of financing the reproduction } \\
\text { directly in the industry through the rearing of } \\
\text { young animals }\end{array}$ \\
\hline $\begin{array}{l}\text { Self- } \\
\text { reproduction }\end{array}$ & $\begin{array}{l}\text { A considerable part of the received production is } \\
\text { not sold on the side, but remains on the farm. It is } \\
\text { not a part of commodity products and does not ac- } \\
\text { quire a monetary form, but takes part in the domes- } \\
\text { tic trade }\end{array}$ & $\begin{array}{l}\text { Special taxation of products involved in in- } \\
\text { ternal - economic turnover }\end{array}$ \\
\hline $\begin{array}{l}\text { The presence } \\
\text { of biological } \\
\text { laws in crop } \\
\text { production } \\
\text { and livestock }\end{array}$ & $\begin{array}{l}\text { Determines the peculiarities of the circulation of } \\
\text { circulating assets of agricultural producers: their } \\
\text { comparative turnover, the gradual increase of costs, } \\
\text { the release of circulating assets from the circulation } \\
\text { at the same time, that is, in the periods of output } \\
\text { and sales }\end{array}$ & $\begin{array}{l}\text { State subsidization of individual industries } \\
\text { and compensation of consumed means of } \\
\text { production }\end{array}$ \\
\hline \multicolumn{3}{|c|}{ Material and technical } \\
\hline $\begin{array}{l}\text { Technical } \\
\text { weapons }\end{array}$ & The level and conditions of use of the equipment & $\begin{array}{l}\text { Creation of depreciation funds, development } \\
\text { of leasing relations }\end{array}$ \\
\hline \multicolumn{3}{|c|}{ Organizational } \\
\hline $\begin{array}{l}\text { Organization } \\
\text { of produc- } \\
\text { tion, labor } \\
\text { and manage- } \\
\text { ment }\end{array}$ & $\begin{array}{l}\text { Displayed of the level of the effectiveness of man- } \\
\text { agement }\end{array}$ & $\begin{array}{l}\text { Application of methods and levers of enter- } \\
\text { prise finance management. Implementation } \\
\text { of financial, tax, insurance, investment man- } \\
\text { agement. }\end{array}$ \\
\hline \multicolumn{3}{|c|}{ Socio-economic } \\
\hline $\begin{array}{l}\text { Capital } \\
\text { expenditure }\end{array}$ & $\begin{array}{l}\text { Displayed on costs and prices of agricultural } \\
\text { products }\end{array}$ & $\begin{array}{l}\text { State and regional programs providing fi- } \\
\text { nancing and capital investments for land ir- } \\
\text { rigation, reconstruction of existing land rec- } \\
\text { lamation systems }\end{array}$ \\
\hline $\begin{array}{l}\text { The price } \\
\text { level of agri- } \\
\text { cultural and } \\
\text { industrial } \\
\text { products }\end{array}$ & $\begin{array}{l}\text { Implementation of agricultural products does not } \\
\text { allow to cover the costs associated with the ac- } \\
\text { quisition of industrial products }\end{array}$ & $\begin{array}{l}\text { State price regulation and support for agri- } \\
\text { cultural production, reserve stocks, reserve } \\
\text { funds, government interventions in com- } \\
\text { modity markets, international trade agree- } \\
\text { ments }\end{array}$ \\
\hline
\end{tabular}


Continue of table 1

\begin{tabular}{|l|l|l|}
\hline Factor & Characteristics of a factor & $\begin{array}{l}\text { Methods of optimizing the influence } \\
\text { of factors }\end{array}$ \\
\hline $\begin{array}{c}\text { Demand for } \\
\text { agricultural } \\
\text { products }\end{array}$ & $\begin{array}{l}\text { The rate of occurrence due to, fluctuations in the } \\
\text { price, quality, seasonality, replacing by other } \\
\text { types of products. }\end{array}$ & $\begin{array}{l}\text { State strategic planning of commodity mar- } \\
\text { kets, long-term agreements and accounting } \\
\text { discipline }\end{array}$ \\
\hline
\end{tabular}

* systematized by the author based on $[1,2,6,7,10]$

Functionally agricultural production is influenced by the regulatory mechanism, as a system of constraints and incentives, which are institutional formations. Institutions of socio-economic relations create institutional norms, form the policy of the state, structure the interaction of all participants of trade through the institutionalization of market processes. The interactions of organizations and institutions in the market mechanism provide the relevant socio-economic "substances" of institutional design. Among them: labor, property, management and regulation, power, social capital, market, competition, entrepreneurship, price, pricing, infrastructure. It is the identification of institutions by importance that reveals their special nature and role in ensuring the economic security of agricultural production.

To institutional formations in the direction of regulating the economic security of agricultural production, we include human capital as a set of ties, a system of socio-economic relations, institutions, collectives, associations, structures, a consolidating factor in the roles of the individual in society and economic activity. Human capital is determined by the number of community associa- tions created, including cooperatives, in a certain territory.

In our opinion, one of the main reasons for not implementing the basic principles of innovative development in the system of regulation of the economic security of the agricultural production is the presence of a set of institutional problems, which, as we propose, consists of: coordination and integration of the components of the new institutional approach to regulation of economic security of agricultural production; integration of economic, social and environmental policies into agricultural policy; improvement of land relations; development of cooperation and integration; increasing the efficiency of the system of state regulation of economic security of agricultural production; instability of agrarian reforms; pricing, budget and tax policies; the absence of a state body to coordinate and integrate the policy of regulating the economic security of agricultural production under current conditions; the absence of non-state structures to protect peasants' interests. The presence of institutional problems has its consequences and results in ensuring the economic security of the agricultural production (table 2).

Table 2

The institutional aspects of regulatory policy economic of security of the agricultural production

\begin{tabular}{|c|c|c|}
\hline Problems & Consequences & Results \\
\hline $\begin{array}{l}\text { Coordination and integration of } \\
\text { components of a new institution- } \\
\text { al approach to regulation of the } \\
\text { economic security of the agricul- } \\
\text { tural production }\end{array}$ & $\begin{array}{l}\text { Strategic planning is not focused } \\
\text { on regulation of the economic se- } \\
\text { curity of the agricultural produc- } \\
\text { tion and planning of the innovative } \\
\text { development }\end{array}$ & $\begin{array}{l}\text { Innovative development is carried out without } \\
\text { taking into account the factors of the econom- } \\
\text { ic security of the agricultural production }\end{array}$ \\
\hline $\begin{array}{l}\text { The instability of agricultural } \\
\text { policy }\end{array}$ & $\begin{array}{l}\text { Frequent changes in the "rules of } \\
\text { the game" }\end{array}$ & $\begin{array}{l}\text { Palliability (negative results) of economic in- } \\
\text { teractions }\end{array}$ \\
\hline Pricing and price politics & $\begin{array}{l}\text { Price disparity, non-equivalence of } \\
\text { inter-sectoral exchange }\end{array}$ & $\begin{array}{l}\text { Shortfall in revenue, losses of individual in- } \\
\text { dustries }\end{array}$ \\
\hline Improvement of land relations & Loss of property & $\begin{array}{l}\text { The non-market nature of the redistribution of } \\
\text { land assets }\end{array}$ \\
\hline $\begin{array}{l}\text { Development of cooperation and } \\
\text { integration }\end{array}$ & Lack of co-operative areas & Losses from marketing actions \\
\hline $\begin{array}{l}\text { Improving the efficiency of the } \\
\text { state regulation of agricultural } \\
\text { production }\end{array}$ & $\begin{array}{l}\text { Absence of self-regulatory struc- } \\
\text { tures }\end{array}$ & $\begin{array}{l}\text { The limited possibilities of professional asso- } \\
\text { ciations }\end{array}$ \\
\hline Protectionism & $\begin{array}{l}\text { Distribution of support not to all } \\
\text { economic entities }\end{array}$ & $\begin{array}{l}\text { Restricting of the ability of entrepreneurs to } \\
\text { operate in equal competition conditions }\end{array}$ \\
\hline $\begin{array}{l}\begin{array}{l}\text { Incompleteness of agrarian } \\
\text { reform }\end{array} \\
\end{array}$ & $\begin{array}{l}\text { Lack of institutional conditions for } \\
\text { land capitalization }\end{array}$ & $\begin{array}{l}\text { Preservation of peasant alienation from the } \\
\text { land; development of the shadow land market }\end{array}$ \\
\hline $\begin{array}{l}\text { The absence of non-government } \\
\text { organizations which protect the } \\
\text { interests of the rural population }\end{array}$ & $\begin{array}{l}\text { Limited opportunities to bring to } \\
\text { power their problems and protect } \\
\text { their interests }\end{array}$ & $\begin{array}{l}\text { Significant divergence of state policy meas- } \\
\text { ures with peasants' real needs }\end{array}$ \\
\hline $\begin{array}{l}\text { Absence of a state body for } \\
\text { coordination and integration of } \\
\text { regulation of the economic secu- } \\
\text { rity of the agricultural production }\end{array}$ & Disability, inefficiency & $\begin{array}{l}\text { Increasing of ecodestructive impact of agricul- } \\
\text { tural production on agro-landscapes }\end{array}$ \\
\hline
\end{tabular}


Continue of table 2

\begin{tabular}{|l|l|l|}
\hline \multicolumn{1}{|c|}{ Problems } & \multicolumn{1}{|c|}{ Consequences } & \multicolumn{1}{c|}{ Results } \\
\hline $\begin{array}{l}\text { Lack of the Institute of Corpo- } \\
\text { rate Social Responsibility }\end{array}$ & $\begin{array}{l}\text { Alienation from the problems of } \\
\text { society }\end{array}$ & Violation of agri-environmental standards \\
\hline
\end{tabular}

* systematized by the authors

The formation of an effective institutional structure of the regulatory policy of the economic security of the agricultural production involves the creation of a favorable motivational climate for the functioning of the agricultural production and marketing of agricultural products; formation of fair market prices that will ensure the equivalence of the reproduction of capital invested in production; improving marketing and agrarian logistics; introduction of innovations and regulation of the general competitiveness of the agricultural production.

That is, agricultural production is defined as a complex socio-economic and at the same time vulnerable agrobiological system of nature and society with diversi- fied functions - life management (production of agro-food and raw materials), livelihoods (employment, conditions and quality of life of economic entities, rural communities, nation as a whole), living arrangement (development of territorial habitat). The rational implementation by the agrarian sector of these various functions serves as a basis for regulating its economic security. The presence of a large number of aspects of regulation of economic security of agricultural production, the difficulty of choosing the optimal variant of its guarantee objectively encourages application of the complex approach to systematization factors (Fig. 2) [9, p. 120].

The purpose of the regulation of economic security of agricultural production - to guarantee its stable and maximally effective functioning in modern conditions and high potential of innovative development in the long term.

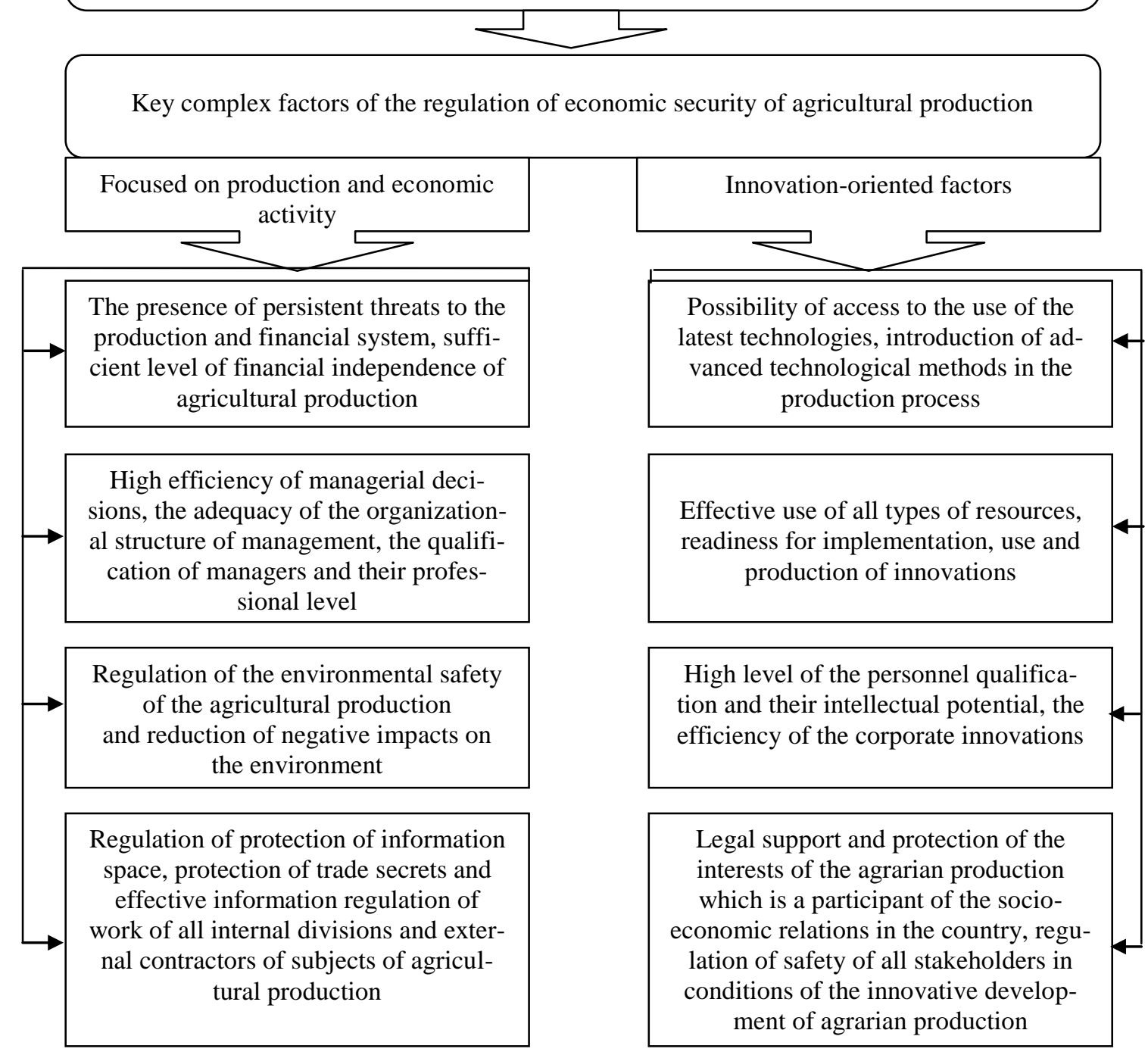

Fig. 2. Complex factors of the regulatory policy of economic security of agricultural production *developed by the authors 
Summarizing the above mentioned, we see that the regulation of the economic security of the agricultural production, is considered as a complex integrated element of the overall system of innovative development of the agricultural production at all levels of its regulation, and provides for the implementation of appropriate measures (organizational, technological, preventive, propaganda, control, protective) in order to counteract the negative impact on the economic security of the agricultural production. In this regard, there is a need to define strategic goals for regulating the economic security of the agricultural production (Fig. 3).

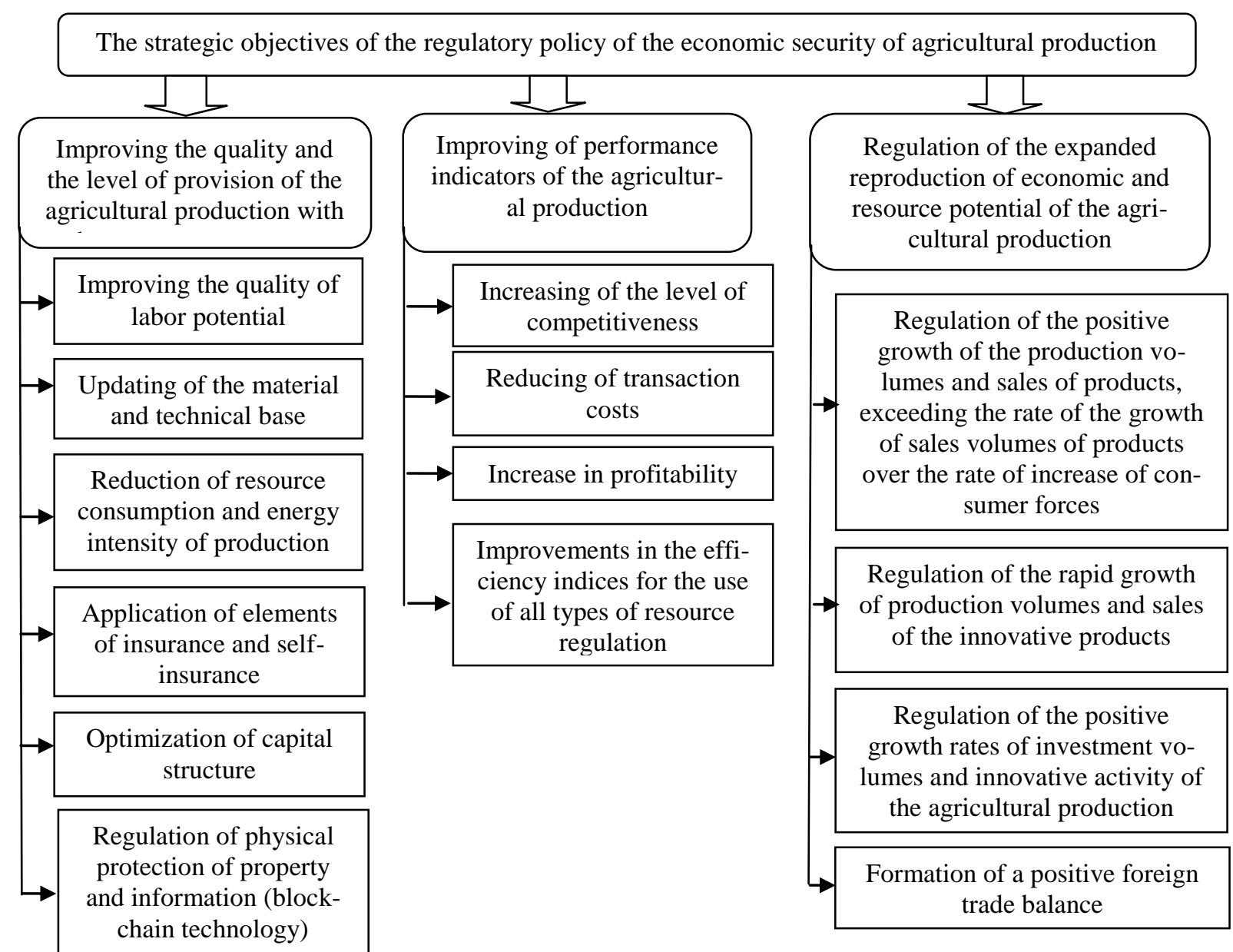

Fig. 3. Strategic objectives of regulatory policy of economic security of agricultural production* * developed by the authors

Conclusions and prospects of the further investigations. Thus, the necessity of separating the factors of influence on the regulation of the economic security according to the following classification criteria is substantiated by the following facts:

1) oriented to industrial and economic activities (the presence of a threat-resistant production and financial system, a sufficient level of financial independence of agricultural production, high efficiency of management decisions, and the adequacy of the organizational structure management, qualification of managers and their professional level; regulation of environmentalists, the integrity of the activities of agricultural production and the reduction of negative environmental impacts in them; regulation of the protection of the information space, observance of trade secrets and effective information regulation of the work of all internal divisions and external contractors of agricultural production entities);

2) innovation-oriented (the ability to access the latest technologies, the introduction of advanced technological methods in the production process, the effective use of all types of resources, the willingness to introduce, use and produce innovations, the high level of staff qualification and their intellectual potential, the effectiveness of corporate innovations; legal support and protection of interests of agricultural production as a participant in socio-economic relations in the country, regulation pretensions of all stakeholders in terms of innovative development of agricultural production). Such an approach made it possible to substantiate the directions of regulating the economic security of agricultural production and propose approaches to choosing the optimal combination of means to counter the threats to the development of the latter. 
The necessity of forming a strategy for ensuring the economic security of the agricultural sector based on innovative development has been proved. The necessity of taking into account socio-economic, national-strategic, demographic and other aspects of ensuring economic security and the implementation of innovative processes in the agricultural sector has been justified, provides for the establishment of optimal relations between financial, credit, industrial, scientific, technical and innovative policies. It is such a relationship that can ensure economic security through the reproduction of the innovation process, and stimulate scientific and technological innovations and technological changes. Consequently, the achievement of a set of strategic goals that we have determined will contribute to the development of specific measures to eliminate threats to the economic security of agricultural production. The combination of such measures and the consideration of the economic security of agricultural production from the standpoint of a systematic regulation will contribute to more practical research results in this direction.

\section{References}

1. Andriichuk, V. H. (2013). Ahropromyslovi formuvannia novoho typu v konteksti stratehii rozvytku vitchyznianoho silskoho hospodarstva. Ekonomika APK, (1), 3-15.

2. Hnatieva, T. M., \& Davydiuk, O. O. (2017). Mekhanizm zabezpechennia komplimentarnosti zakhystu ekonomichnykh interesiv ahrarnoho vyrobnytstva. Naukovi Zapysky Instytutu Zakonodavstva Verkhovnoi Rady Ukrainy, (5), 80-89.

3. Hryshova, I. Yu., \& Fedorkin, D. V. (2017). Kontseptualnyi pidkhid shchodo derzhavnoho upravlinnia ekolohichnoiu bezpekoiu ahrarnoho vyrobnytstva. Naukovi Zapysky Instytutu Zakonodavstva Verkhovnoi Rady Ukrainy, (6), 161-167. Retrieved August 20, 2019, from https://instzak.com/index.php/journal/article/view/53

4. Kozlovskyi, S. V., \& Zhurakivskyi, Ye. S. (2015). Teoretyko-metodolohichni pidkhody do vyznachennia katehorii «ekonomichna bezpeka» ta skladovykh ekonomichnoi bezpeky Ukrainy. Ekonomika Ta Derzhava, (6), $37-42$.

5. Konarivska, O. B., \& Paniuk, T. P. (2017). Pidkhody do vyvchennia sutnosti poniattia «ekonomichna bezpeka pidpryiemstv». Naukovyi Visnyk VIEM, (19), 95-103.

6. Kushnir, S. O. (2017). Derzhavna pidtrymka ahropromyslovoho kompleksu Ukrainy. Ukrainskyi Zhurnal Prykladnoi Ekonomiky, 2(1), 48-56.

7. Malik, M. Y., \& Shpykuliak, O. H. (2010). Instytutsionalizatsiia ahrarnoho pidpryiemnytstva: transformatsiia ta efektyvnist. Ekonomika APK, (7), 132-139.

8. Nikoliuk, O. V. (2018). Teoretyko-metodolohichni zasady instytutsiinoho rehuliuvannia sotsialnoekonomichnoi bezpeky ahrarnoho vyrobnytstva. Odesa: Drukarskyi dim, Druk Pivden.

9. Rusan, V., \& Diachenko, O. (2019). Instytutsiini zasady rozvytku ahrarnoho sektoru u konteksti zabezpechennia ekonomichnoi bezpeky derzhavy. Naukovi Zapysky Instytutu Zakonodavstva Verkhovnoi Rady Ukrainy, (2), 117-122. doi: 10.32886/instzak.2019.02.12

10. Sabluk, P. T. (1997). Osoblyvosti ahrarnoi reformy v Ukraini. Kyiv: ZAT "Nichlava."

11. Gryshova, I. Ju., Voronzhak, P. V., \& Shestakovska, T. L. (2017). The implementation of the principles of consumerism in the strategy of the development of business. Naukovyi Visnyk Polissia, (2 (10), Ch. 1), 41-48. doi: 10.25140/2410-9576-2017-1-2(10)-41-48

12. Gryshova, I., Petrova, M., Tepavicharova, M., Diachenco, A., \& Gutsul, T. (2019). A model for selection of a management team to ensure the sustainability and development of the business organizations. Entrepreneurship and Sustainability, (7 (1), 690-703. doi: 10.9770/jesi.2019.7.1(49)

13. Kuprina, N., Stupnytska, T., Vaskovska, K., Boyko, O., Baraniuk, Kh., \& Markova, T. (2019). Managing the competitiveness of the enterprise in the context of transformational change. International Journal of Recent Technology and Engineering, 8(2), 4909-4914. Retrieved August 2, 2019, from https://www.ijrte.org/wpcontent/uploads/papers/v8i2/B3706078219.pdf doi: 10.35940/ijrte.B3706.078219

14. Myshchak, I. (2018). Problemy i perspektyvy zakonodavchoho zabezpechennia innovatsiinoho rozvytku v Ukraini. Naukovi Zapysky Instytutu Zakonodavstva Verkhovnoi Rady Ukrainy, (6), 34-43. doi: 10.32886/instzak.2018.06.05

15. Stupnytska, T., Kalaman, O., \& Markova, T. (2019). Ensuring of the enterprise operation efficiency: management aspect. Periodicals of Engineering and Natural Sciences, 7(2), 534-545. Retrieved August 10, 2019, from http://pen.ius.edu.ba/index.php/pen/article/view/567. 
Гришова И.Ю.

доктор экономических наук, профессор Цяньсуский педагогический университет 101 Шанхай-роуд, Таншань, Сюйчжоу Ши, Цзянсу, Китай, 221100

E-mail:6020180146@jsnu.edu.cn ORCID ID: 0000-0001-6276-7619
Николюк Е.B.

доктор экономических наук, доцент кафедра менеджмента и логистики

Одесская национальная академия пищевых технологий ул. Канатная, 112, г. Одесса, Украина, 65039

E-mail: alenavn11@gmail.com

ORCID ID: 0000-0002-1665-0361

\section{Марчук Л.Л. \\ кандидат экономических наук, преподаватель кафедра экономики и управления \\ Одесская государственная академия технического регулирования и качества ул. Кузнечная, 15 м. Одеса, Украина, 65020 \\ E-mail: IIm.15456@gmail.com}

\section{ИНСТИТУЦИОНАЛЬНЫЕ АСПЕКТЫ РЕГУЛИРОВАНИЯ ЭКОНОМИЧЕСКОЙ БЕЗОПАСНОСТИ АГРАРНОГО ПРОИЗВОДСТВА}

В статье рассмотрено регулирование экономической безопасности аграрного производства, как сложный комплексный элемент общей системы инновационного развития аграрного производства на всех уровнях его регулирования, и предполагает выполнение соответствующих мероприятий (организационно-технологических, профилактических, пропагандистских, контролирующих, защитных), применяемых с целью нейтрализации негативного влияния на экономическую безопасность аграрного производства. В связи с этим определены стратегические цели регулирования экономической безопасности аграрного производства, что будет способствовать разработке конкретных мер по устранению угроз в данной сфрере. Представлен перечень институциональных фракторов (экономические, экологические, социальные и технико-технологические) и составляющих регулирования экономической безопасности аграрного производства, комплексный набор которых обеспечивает точное отображение сущности и направленности опасностей и угроз, воздействия которых может понести национальная экономика, в частности аграрное производство в процессе своего функционирования и инновационного развития.

Доказана необходимость формирования стратегии обеспечения экономической безопасности аграрного сектора на основании инновационного развития. Обосновано необходимость учета социально-экономических, национально-стратегических, демографических и других аспектов обеспечения экономической безопасности и реализации инновационных процессов в аграрном секторе, что предусматривает налаживание оптимальных связей фринансово-кредитной, промышленной, научнотехнической и инновационной политик. Именно такая связь способна обеспечить экономическую безопасность на основании развития инновационного процесса, стимулировать научнотехнологические новшества и технического прогресса.

Ключевые слова: экономическая безопасность, аграрное производство, регуляторная политика, институциональные аспекты, стратегия, инновационное развитие.

Гришова І.Ю.

доктор економічних наук, профессор

Цянсуський педагогічний університет

101 Шанхай-роуд, Тоншань, Сюйчжоу Ши, Цзянсу, Китай, 221100

E-mail:6020180146@jsnu.edu.cn ORCID ID: 0000-0001-6276-7619
Ніколюк О.В.

доктор економічних наук, доцент кафедра менеджменту та логістики Одеська національна академія харчових технологій,

вул. Канатна, 112, м. Одеса, Україна, 65039

E-mail: alenavn11@gmail.com

ORCID ID: 0000-0002-1665-0361

Марчук Л.Л.

кандидат економічних наук, викладач

кафедра економіки та управління

Одеська державна академія технічного регулювання та якості, вул. Ковальська, 15, м. Одеса, Україна, 65020

E-mail: IIm.15456@gmail.com

\section{ІНСТИТУЦІЙНІ АСПЕКТИ РЕГУЛЮВАННЯ ЕКОНОМІЧНОЇ БЕЗПЕКИ АГРАРНОГО ВИРОБНИЦТВА}

У статті розглянуто регулювання економічної безпеки аграрного виробництва, як складний комплексний елемент загальної системи інноваційного розвитку аграрного виробництва на всіх рівнях 
його регулювання, і передбачає виконання відповідних заходів (організаційно-технологічних, профрілактичних, пропагандистських, контролюючих, захисних), які вживаються з метою нейтралізації негативного впливу на економічну безпеку аграрного виробництва. У зв'язку з цим визначено стратегічні цілі регулювання економічної безпеки аграрного виробництва, що сприятиме розробці конкретних заходів щодо усунення загроз у даній сфері. Представлено перелік інституційних факторів (економічні, екологічні, соціальні та техніко-технологічні) та складових регулювання економічної безпеки аграрного виробництва, комплексний набір яких забезпечує найточніше відображення сутності та спрямованості небезпек та загроз, впливу яких може зазнати національна економіка, зокрема аграрне виробництво у процесі свого функціонування та інноваційного розвитку.

Доведено необхідність фрормування стратегії забезпечення економічної безпеки аграрного сектору на засадах інноваційного розвитку. Обґрунтовано необхідність врахування соціальноекономічних, національно-стратегічних, демографрічних та інших аспектів забезпечення економічної безпеки та реалізації інноваційних процесів в аграрному секторі, що передбачає налагодження оптимальних зв'язків фрінансово-кредитної, промислової, науково-технічної та інноваційної політик. Саме такий зв'язок спроможний забезпечити економічну безпеку на основі відтворення інноваційного процесу, стимулювати науково-технологічних нововведень і технічних зрушень.

Ключові слова: економічна безпека, аграрне виробництво, регуляторна політика, інституційні аспекти, стратегія, інноваційний розвиток.

\section{Література}

1. Андрійчук В.Г. Агропромислові формування нового типу в контексті стратегії розвитку вітчизняного сільського господарства // Економіка АПК. - 2013. № 1. С. 3-15.

2. Гнатьєва Т.М., Давидюк О.О. Механізм забезпечення компліментарності захисту економічних інтересів аграрного виробництва // Наукові записки Інституту законодавства Верховної Ради України. 2017. № 5. С. 80-89.

3. Гришова, І.Ю, Федоркін Д.В. (2017). Концептуальний підхід щодо державного управління екологічною безпекою аграрного виробництва //Наукові записки Інституту законодавства Верховної Ради України. 2017. № 6, С. 161-167. URL: https://instzak.com/index.php/journal/article/view/53 (дата звернення 20.08.2019)

4. Козловський С. В., Жураківський С. С. Теоретико-методологічні підходи до визначення категорії «економічна безпека» та складових економічної безпеки України. Економіка та держава. 2015. № 6. С. 37-42.

5. Конарівська О.Б., Панюк Т. П. Підходи до вивчення сутності поняття «економічна безпека підприємств» // Науковий Вісник ВІЕМ. Луцьк. 2017. №19 С. 95-103.

6. Кушнір С.О. Державна підтримка агропромислового комплексу України // Український журнал прикладної економіки. 2017. Том 2, №1. С. 48-56.

7. Малік М.Й., Шпикуляк О.Г. Інституціоналізація аграрного підприємництва: трансформація та ефективність // Економіка АПК. 2010. № 7. С. 132-139.

8. Ніколюк О.В. Теоретико-методологічні засади інституційного регулювання соціально-економічної безпеки аграрного виробництва: монографія. Одеса: Друкарський дім, Друк Південь, 2018. 298 с.

9. Русан В., Дяченко О. (2019). Інституційні засади розвитку аграрного сектору у контексті забезпечення економічної безпеки держави // Наукові записки Інституту законодавства Верховної Ради України. 2019. № 2. C. 117-122. URL: https://doi.org/10.32886/instzak.2019.02.12 (дата звернення 10.08.2019) doi: 10.32886/instzak.2019.02.12

10. Саблук П.Т. Особливості аграрної реформи в Україні. К.: ЗАТ “Нічлава”, 1997. 304 с.

11. Gryshova, I. Ju., Voronzhak P.V., Shestakovska T. L. The implementation of the principles of consumerism in the strategy of the development of business // Науковий вісник Полісся. 2017. № 2 (10), Ч. 1. С. 4148 doi: 10.25140/2410-9576-2017-1-2(10)-41-48

12. A model for selection of a management team to ensure the sustainability and development of the business organizations / Gryshova I. and others // Entrepreneurship and Sustainability. 2019. Issue 7(1). P. 690-703. URL: https://doi.org/10.9770/jesi.2019.7.1(49) (дата звернення 10.08.2019)

13. Managing the competitiveness of the enterprise in the context of transformational change / Kuprina N. and others // International Journal of Recent Technology and Engineering. 2019. Vol 8, Issue 2, (July ), P. 4909-4914. URL: https://www.ijrte.org/wp-content/uploads/papers/v8i2/B3706078219.pdf, India, Scopus (дата звернення 2.08.2019) doi: $10.35940 /$ ijrte.B3706.078219

14. Myshchak, I. (2018). Проблеми і перспективи законодавчого забезпечення інноваційного розвитку в Україні // Наукові записки Інституту законодавства Верховної Ради України. 2018. № 6. С. 34-43. URL: https://doi.org/10.32886/instzak.2018.06.05 (дата звернення 10.08.2019) 
15. Stupnytska T., Kalaman O., Markova T. Ensuring of the enterprise operation efficiency: management aspect // Periodicals of Engineering and Natural Sciences. 2019, Vol 7, №2 (August), P. 534-545. URL:http://pen.ius.edu.ba/index.php/pen/article/view/567, Bosnia, Scopus (дата звернення 10.08.2019)

Стаття надійшла 12.08.2019 Стаття прийнята до друку 26.08.2019 Доступно в мережі Internet 16.10.2019

Цитування згідно ДСТУ 8302:2015

Gryshova I., Nikoliuk O., Marchuk L. Institutional aspects of the regulation of economic security of the agricultural production // Food Industry Economics. 2019. Vol.11, Issue 3. P. 23-32. doi: 10.15673/fie.v11i3.1458

Cite as APA style citation

Gryshova, I., Nikoliuk, O., \& Marchuk, L. (2019). Institutional aspects of the regulation of economic security of the agricultural production. Food Industry Economics, 11(3), 23-32. doi: 10.15673/fie.v11i3.1458 